\title{
AS FUNÇÕES DE ESTADO NA ÁREA FLORESTAL: SUAS INTER- RELAÇÕES COM A CONSTITUIÇÃO FEDERAL E COM O PROGRAMA NACIONAL DE FLORESTAS
}

\author{
José das Dores de Sá Rocha ${ }^{1}$, José de Arimatéa Silva ${ }^{2}$ \\ ${ }^{1}$ Eng. Florestal, M.Sc., Seropédica, RJ, Brasil - asufrrj@hotmail.com \\ ${ }^{2}$ Eng. Florestal, Dr., Depto. de Silvicultura, UFRRJ, Seropédica, RJ, Brasil - arimatea@ufrrj.br \\ Recebido para publicação: 04/07/2007 - Aceito para publicação: 10/09/2008
}

\begin{abstract}
Resumo
As funções de Estado na área florestal, apresentadas por Silva (2001 e 2003), foram primeiramente investigadas, contextualizando-se suas origens numa leitura do surgimento e evolução do Estado e das suas inter-relações com a Constituição Federal brasileira de 1988. Em segundo lugar, investiga-se se há correspondências entre as funções de Estado e o conteúdo de política pública florestal, expresso no Programa Nacional de Florestas (PNF). Para efeito deste estudo, consideraram-se duas gestões de governo: período 2000 a 2003 (PNF-2000) e período 2003 a 2006 (PNF-2004), tendo sido o programa reafirmado no ano de 2004. Num terceiro momento, realizou-se uma pesquisa que consistiu na aplicação de questionários a membros da Comissão Coordenadora do Programa Nacional de Florestas (Conaflor), sobre o atendimento das funções de Estado na área florestal. A pesquisa versa sobre as perguntas ao entrevistado: se considera válida a função de Estado na área florestal ou não; se o Estado vem cumprindo a referida função; se o PNF tem contribuído para que a função seja desenvolvida. As principais conclusões são: as funções de Estado encontram sustentação constitucional; o PNF permeia as funções de Estado na área florestal, embora não plenamente; os entrevistados reconhecem as funções de Estado na área florestal como válidas, ainda que o Estado não as venha desenvolvendo na sua plenitude.
\end{abstract}

Palavras-chave: Funções de Estado na área florestal; política florestal; Programa Nacional de Florestas.

\begin{abstract}
The state functions in the forest sector: Its relationship with the Federal Constitution and with the Forest National Program. The functions of State in the forest area, presented by Silva (2001 e 2003), were investigated firstly, composing its origins in an understanding of the State emergence and evolution and its inter-relationship with the Brazilian Federal Constitution of 1988. Secondly, this correspondences were investigated in the expressed content of forest public politics in the National Program of Forests (PNF). The two government administrations were considered: period 2000 to 2003 (PNF-2000), and period 2003 to 2006 (PNF-2004), since the program was reaffirmed in the year of 2004. Third, took place a research that consisted on questionnaire application to the members of the Coordinating Commission of the National Program of Forests (Conaflor) about the attendance of the functions of State in the forest area. The research consisted on the questions to the interviewee: if it is considered the function of State in the forest area or not; if the State is executing the referred function; if PNF has been contributing for the function development. The main conclusions are: that the functions of State find Constitutional support; PNF permeates the State functions in the forest area, although that still not entirely; the interviewees recognize the functions of State in the forest area as valid, although the State doesn't come developing them in its fullness.

Keywords: Functions of State forest area; forest politics; Program National of Forests.
\end{abstract}

\section{INTRODUÇÃO}

A política florestal, ramo da ciência florestal, encontra-se em processo de superação teórica para atingir sua finalidade em sua plenitude: orientar a práxis política. 
A teoria política florestal, a despeito da sua evolução nos últimos 50 anos, está a requerer, no caso brasileiro, a superação de etapas fundamentais para cumprir na sua plenitude o seu papel, que é o de servir de alicerce do processo político florestal. Comparativamente a outras áreas da Engenharia Florestal (Silvicultura, Dendrometria e Inventário, Economia Florestal, Tecnologia de Produtos Florestais), essa área tem apresentado pouca produção acadêmica no Brasil, a despeito de colocar-se no topo de uma pirâmide da ciência florestal sistematizada.

A política florestal centra-se na determinação de um curso de ação para alcançar objetivos gerais e específicos. Portanto, a formulação de qualquer política, assim como da política florestal, se assenta no princípio do bem comum. Logo, há a necessidade de estabelecimento de princípios e do lineamento, erigidos em bases sólidas, com vistas orientar a formulação de políticas públicas florestais.

Nos anos 60 do século XX, o Professor Newton Carneiro, da Faculdade de Florestas de Curitiba, trouxe à tona os primeiros escritos sobre conceitos e princípios de orientação à formulação da política pública florestal no Brasil (CARNEIRO, 1968). Mais recentemente, Santos (1993) apresentou contribuições sobre a formulação de política florestal para o Brasil. E, numa abordagem hodierna do processo político florestal europeu, Aicher (2004) apontou tendências de mudanças conceituais da política florestal, advindas da globalização das questões ambientais e dos novos processos sociais, todavia não tratou da política florestal brasileira.

A política florestal brasileira, enquanto ramo das ciências sociais integrante da ciência florestal, tem sido pouco abordada em periódicos científicos, assim como em outros meios de divulgação e comunicação da ciência florestal no Brasil. Contudo, os esforços da ciência política, sem prejuízo de seus avanços, ao focar a área florestal, tem-se abstido dos princípios de onde emanam, tendo em vista que as definições correntes de política florestal, assim como as suas conceituações, via de regra apresentam-se desvinculadas dos fundamentos que lhe dão sustentação e dos meios e fins de sua existência.

Evidencia-se a necessidade de, no âmbito da ciência política, buscar-se a superação conceitual da política florestal, de modo a elucidar-se a sua inter-relação com o Estado e a sociedade, assim como dos elos entre ambos. Trata-se, portanto, do estudo do liame do poder legal estatuído com a vida cotidiana dos cidadãos, ou seja, a emanação do poder estatal na sociedade atinente à temática florestal e suas relações recíprocas.

Trata-se, dentre outros aspectos, de trazer à tona uma discussão sobre as funções de Estado na área florestal, visando atribuir sentido e sustentação às conceituações de política pública florestal, de modo a subsidiar o diálogo Estado-sociedade e oferecer um lineamento de estudo do processo político em questão.

Este estudo objetiva:

- fazer uma revisão histórico-evolutiva da relação Estado-sociedade e das funções do Estado, estabelecendo o liame entre os princípios históricos do surgimento deste com as suas funções na área florestal;

- explicitar as inter-relações das funções de Estado na área florestal estabelecidas por Silva (2001 e 2003) com disposições da Constituição Federal de 1988;

- analisar as funções de Estado no conteúdo de política pública florestal expresso no Programa Nacional de Florestas (PNF) e como se dá a percepção dessas funções pelos membros da Comissão Coordenadora do Programa Nacional de Florestas (Conaflor) ${ }^{1}$.

\section{MATERIAL E MÉTODOS}

\section{Fonte de dados e informações}

As fontes de consulta, extração de dados e conteúdo de política pública florestal brasileira do presente estudo foram o decreto de criação (Decreto $\mathrm{n}^{\circ} 3.420$, de 20 abril de 2000) e os documentos do PNF.

Para efeito da análise do curso de ação, que corresponde ao conteúdo da política pública florestal, consideraram-se:

\footnotetext{
${ }^{1}$ Após a realização da pesquisa do presente trabalho, o Decreto n ${ }^{\circ}$ 5.794, de 5 de junho de 2006, alterou a denominação da Comissão Coordenadora do Programa Nacional de Florestas para Comissão Nacional de Florestas, mantendo, no entanto, a mesma sigla.
} 
i. As linhas temáticas do PNF criado em abril de 2000 e lançado em setembro do mesmo ano pelo Presidente Fernando Henrique Cardoso, extraídas diretamente do documento do programa, publicado no ano seguinte pelo Ministério do Meio Ambiente (PNF, 2001), o qual estabelece os temas de forma clara, justamente com o título: Linhas temáticas.

ii. As linhas de ação do PNF, reajustadas em fevereiro de 2004, extraídas do documento distribuído na cerimônia oficial de relançamento do Programa e criação da Conaflor pelo Presidente Luís Inácio Lula da Silva, além dos documentos fornecidos diretamente pela direção do PNF (PNF, 2004).

O conteúdo de política pública florestal corresponde ao teor do planejamento do poder público federal, expresso como programa ou plano de gestão governamental. Entende-se, para efeitos do estudo, que no conteúdo programático esteja explícito claramente o curso de ação (ações a serem implementadas, ou seja, objetivos e metas), os beneficiários das ações, bem como os instrumentos e mecanismos para a consecução dos objetivos e metas, extraídos e construídos no seio da sociedade.

\section{Variáveis analisadas e técnicas aplicadas}

Foi realizada uma pesquisa com os membros da Conaflor (Decreto $\mathrm{n}^{\circ} 4864$, de 24/10/2003) por ocasião do Seminário de Imersão e Nivelamento do PNF/Conaflor, ocorrido nos dias 16, 17 e 18 de junho de 2005, em Manaus, estado do Amazonas.

A Conaflor, composta por representantes do governo federal, governos estaduais e segmentos sociais ligados ao setor florestal, é o espaço institucionalizado de representação social no processo político florestal, com a prerrogativa de propor medidas e acompanhar a política pública florestal brasileira.

Foram aplicados três questionários abertos e fechados aos membros da Comissão presentes na reunião, dos quais 12 responderam os questionários, que não requeriam identificação.

O primeiro questionário continha a pergunta "Você considera como função típica de Estado na área florestal":

1. Realizar o macro planejamento da proteção e utilização dos recursos florestais.

2. Administrar as áreas florestais públicas.

3. Prestar assistência técnica e extensão florestal.

4. Promover o fomento da atividade florestal.

5. Realizar a pesquisa florestal.

6. Monitorar, controlar e fiscalizar a cobertura florestal dos proprietários privados.

Para os seis itens, as opções de resposta eram "sim", "em parte" e "não".

O segundo questionário continha os mesmos itens, com a seguinte pergunta: "O Estado vem desenvolvendo esta função?". O terceiro questionário, também com os mesmos itens, indagava: "O PNF tem contribuído para que esta função seja desenvolvida?".

Para os questionários dois e três, as opções de resposta, para todos os itens, eram: plenamente, razoavelmente, precariamente, não desenvolve ou não tem contribuído. Adicionalmente, o respondente deveria atribuir, para cada item, uma nota de 0 a 10.

Os três questionários aplicados continham ainda espaço para sugestões livres dos respondentes, para qualquer dos itens. Preenchidos, os questionários foram depositados numa urna, para posterior processamento das respostas.

Sendo o foco do estudo o processo político florestal, sob o aspecto da democracia participativa, a Conaflor constituiu a amostra de interesse desta pesquisa. Essa Comissão corresponde à arena política, ou seja, o locus de conflito e barganha, e, ao mesmo tempo, o canal de capilaridade social, este constituído pela sociedade e o Estado.

\section{Análise dos dados}

Para responder ao primeiro objetivo, realizou-se uma revisão de bibliografia sobre Estado e sociedade, enfocando o surgimento e a evolução das funções de Estado na sociedade, no sentido amplo, remetendo à questão florestal, valendo-se de autores clássicos sobre o tema (Estado e sociedade).

No que diz respeito à resposta do segundo objetivo, procedeu-se à explanação das funções de Estado na área florestal apresentadas por Silva (2001 e 2003) e buscaram-se inter-relações dessas funções em artigos da Constituição Federal brasileira de 1988. 
O atendimento do terceiro objetivo deu-se através de dois procedimentos: primeiro, estabeleceram-se relações entre as funções de Estado evidenciadas por Silva (2001 e 2003) e as linhas de ação do PNF; segundo, analisaram-se as respostas e sugestões obtidas na pesquisa (questionários aplicados à Conaflor), as quais foram tabuladas e processadas para a obtenção dos resultados relativos aos itens constantes dos questionários. A análise consistiu na averiguação da porcentagem em relação ao total de respostas para cada um dos itens, processadas através do programa Microsoft Office Excel.

As respostas do primeiro questionário destinavam-se a averiguar o grau de aceitação do arcabouço teórico utilizado para o presente estudo no que se refere às funções de Estado na área florestal. As do segundo tinham por propósito evidenciar, em termos relativos, o desenvolvimento dessas funções pelo Estado. E, por último, as respostas do terceiro questionário objetivavam verificar o nível de contribuição do PNF para a realização das funções de Estado elencadas na pesquisa.

\section{RESULTADOS E DISCUSSÃO}

\section{Estado, sociedade e comunidade - processo evolutivo}

Aristóteles afirma que a união entre o homem e a mulher, o senhor e o escravo, forma, antes de qualquer coisa, a família. O conjunto de muitas famílias constitui a sociedade, "o pequeno burgo", visando a utilidade comum. A sociedade, formada por inúmeros pequenos burgos constitui uma cidade, provida com os meios para suprir sua subsistência e finalidade de um viver feliz. Por essa razão, toda sociedade se integra na natureza, visto que a natureza foi quem formou as primeiras sociedades. A natureza é, portanto, o real fim de todas as coisas. Todavia, se a cidade é parte da natureza, e o homem participa da cidade, logo, o homem é um ser político por natureza. Sendo assim, se um ser não participa da sociedade por instinto, e não por alguma inibição de qualquer circunstância, este é um ser vil ou superior ao homem (ARISTÓTELES, 2006).

O significado do substantivo abstrato sociedade é a forma genérica para expressar "todo o complexo de relações do homem com seus semelhantes", segundo Talcott Parsons, citado por Bonavides (2005).

Os conceitos de sociedade provêm de duas perspectivas, uma mecanicista e outra orgânica. Sob a perspectiva mecanicista, Bonavides (2005) faz remissão a Toonnies, que define sociedade como um "grupo derivado de um acordo de vontades, de membros que buscam, mediante o vínculo associativo, um interesse comum impossível de obter-se pelos esforços isolados dos indivíduos". Por outro lado, contrapondo-se à idéia mecanicista, o autor faz alusão a Del Vecchio, que define sociedade como "o conjunto de relações mediante as quais grupos de indivíduos convivem solidariamente de modo a formar uma entidade nova e superior". Numa outra leitura: "É uma reunião de várias partes, que preenchem funções distintas e que por sua ação combinada concorrem para manter a vida do todo", atribuindo a esses pronunciamentos uma visão eminentemente organicista. A teoria organicista se fundamenta no tronco milenar da filosofia grega, que descende de Aristóteles e Platão.

Maturana (1998) diz que a "convivência social se funda e se constitui na aceitação, no respeito e na confiança mútuos, criando assim um mundo comum”. E nessa aceitação, assevera, é que se funda a liberdade social. Isso é assim porque a constituição biológica humana é a de um ser que vive no cooperar e no compartir, de modo que a perda da convivência social traz consigo a enfermidade e o sofrimento.

Para Dallari (2005), a origem da sociedade é expressa sob dois aspectos: o primeiro se funda na ideia da sociedade natural, ou seja, fruto da própria natureza humana; o segundo sustenta que a sociedade é, tão-só, a consequência de uma escolha.

Discorrendo sobre a ideia do homem social por natureza, Dallari (2005) considera que ela surgiu e evoluiu principalmente com Aristóteles, Cícero e Santo Tomás de Aquino. Para Aristóteles, "o homem é naturalmente um animal político"; para Cícero, "a primeira causa da agregação de uns homens a outros é menos a sua liberdade do que um certo instinto de sociabilidade em todos inato; a espécie humana não nasceu para o isolamento e para a vida errante, mas com uma disposição que, mesmo na abundância de todos os bens, a leva a procurar o apoio comum"; para Santo Tomás de Aquino, filiado à corrente aristotélica, "o homem é, por natureza, animal social e político, vivendo em multidão, ainda mais que todos os outros animais, o que se evidencia pela natural necessidade". Na mesma linha, o autor faz ainda remissão a Oreste Ranalletti, que afirma: "O homem é induzido fundamentalmente por uma necessidade natural, porque o associar-se com os outros seres humanos é para ele condição essencial de vida". 
Portanto, entende-se que somente na convivência e com a cooperação dos semelhantes o homem pode beneficiar-se da energia, do conhecimento, da produção e da experiência dos outros - atributos estes acumulados através das gerações. Assim, ele obtém os meios necessários para atingir os fins de sua existência, desenvolvendo todo o seu potencial de aperfeiçoamento no campo intelectual, moral ou técnico; em outras palavras, a expansão das capacidades e desenvolvimento humanos. Nessa perspectiva, o autor conclui que a sociedade é fruto da conjugação de um simples impulso associativo natural com a cooperação do anseio humano.

Em oposição à filiação do fundamento natural da sociedade, apresenta-se o contratualismo, emanado da ideia de que a sociedade é, tão-só, o produto de um acordo de vontades, ou seja, a celebração de um contrato hipotético entre os homens. Os contratualistas divergem quanto ao motivo que leva o homem a unir-se e viver em sociedade. Platão, com a obra "A República", Thomas Moore, com a "Utopia", e Tommaso Campanella, com "a Cidade do Sol", são os principais teóricos dessa linha. Esses pensadores apresentam como ponto em comum "a total submissão da vida social à razão e à vontade" e descrevem a organização social à parte das mazelas e dos problemas vividos pelas sociedades, sem estabelecer conexões entre as suas origens e as idealizações.

Hobbes (1974) apresenta uma sistematização doutrinária, considerando o homem em "estado da natureza" não só no estágio primitivo, do ponto de vista histórico, como também na ausência de poder de um sistema político instituído. E postula duas leis fundamentais que levam o homem do estado da natureza ao estado social, superando as paixões em favor dos princípios racionais que dão a base da vida social: i) cada homem deve esforçar-se pela paz, enquanto tiver a esperança de alcançá-la; e quando não puder obtê-la, deve buscar e utilizar todas as ajudas e vantagens da guerra; ii) cada um deve consentir - se os demais também concordam, e enquanto se considere necessário para a paz e a defesa de si mesmo em renunciar ao direito a todas as coisas, e a satisfazer-se, em relação aos demais homens, com a mesma liberdade que lhe for concedida com respeito a si próprio. Conscientes dessas leis, os homens ratificam o "contrato" de recíprocos direitos de um para com o outro, estabelecendo a vida em sociedade, por essa força claramente racional. A sua preservação requer a corporificação de um poder que mantenha os homens dentro dos limites definidos em lei, que os faça cumprir seus deveres, por temor à coação. E "esse poder visível (corporificado) é o Estado, um grande e robusto homem artificial, construído pelo homem natural para sua proteção e defesa".

O conceito de Estado emanado daí considera como "uma pessoa de cujos atos se constitua em autora uma grande multidão, mediante pactos recíprocos de seus membros, com o fim de que essa pessoa possa empregar a força e os meios todos, como julgar conveniente, para assegurar a paz e a defesa comuns". Dallari (2005) evidencia que a obra de Hobbes, que exerceu forte influência na nobreza inglesa, oferece uma sugestão ao absolutismo.

Emerge no fim do século XVII a contraposição à concepção contratualista, começando na própria Inglaterra e fortalecendo-se na França no século seguinte. Dallari (2005) considera que, mesmo os que se opõem ao contratualismo de Hobbes, fazem uso dele para explicar a origem da sociedade. Exemplo disso é Montesquieu (1973), em sua obra "Do Espírito das Leis", ao considerar o "homem em estado natural anterior ao estabelecimento da sociedade", assinalando a existência de leis naturais que levam o homem a optar pela vida em sociedade. Todavia, Montesquieu não chega a expressar o contrato social, atendo-se às leis do governo.

Rousseau (1973) elucidou os princípios contratualistas que influenciaram a Revolução Francesa, e ainda hoje suas ideias constituem os fundamentos da democracia contemporânea. Remanescem do seu pensamento a concepção de povo soberano, assim como o reconhecimento da igualdade como o pilar essencial da sociedade. Sobre o interesse comum e o interesse particular, assim se expressa: "Há, às vezes, diferença entre a vontade de todos e a vontade geral: esta atende só ao interesse comum, enquanto que a outra olha o interesse privado e não é senão uma soma das vontades particulares...”. Logo, pode-se interpretar que a vontade geral tende à utilidade pública. E postula que a finalidade de toda legislação é proteger o maior bem de todos: a liberdade e a igualdade. Dessa forma, justifica a afirmação da existência de uma liberdade natural e ao mesmo tempo uma igualdade natural, que a sociedade busca proteger e não aniquilar; e que o pacto procede a uma correção, visando suprir as deficiências emanadas das disparidades físicas, tornando assim os homens, mesmo diferentes em força ou engenhosidade, iguais, vivendo em sociedade, tornando-se iguais por convenção e direito. 
Dallari (2005) considera que as sociedades de fins gerais são denominadas "sociedades políticas" pelo fato de não se aterem a um objetivo determinado de setores limitados da atividade humana, integrando no seu âmbito as atividades sociais. Logo, a maior sociedade política, com capacidade de influir e condicionar, é o Estado. Daí extrai a primeira noção de Estado, procurando incorporar todos os seus elementos, com ênfase no componente jurídico, mas sem perder de vista a necessária incorporação de fatores não jurídicos. E conceitua Estado, finalmente, como "a ordem jurídica soberana que tem por fim o bem comum de um povo situado em determinado território". Argumenta a seguir que a noção de poder está implícita na de soberania, caracterizada como a própria ordem jurídica. Assim, a politicidade do Estado é associada ao bem comum do povo, e a territorialidade é limitadora da ação jurídica e política do Estado.

Segundo Bobbio (2004), sociedade civil (societas civilis) refuta a sociedade natural (societas naturalis), sendo sinônimo de sociedade política, com derivação de civitas e de polis, e consequentemente de Estado.

Bonavides (2005) apresenta a distinção entre sociedade e comunidade, afirmando que são duas formas básicas de convivência humana opostas. Interpretando Toonnies, o autor considera que a sociedade supõe "ação conjunta e racional dos indivíduos no seio da ordem jurídica e econômica; nela os homens, a despeito de todos os laços, permanecem separados", ao passo que, na comunidade, "os indivíduos estão unidos, a despeito de tudo aquilo que os separa". Nela há formas de vida e organização social, baseadas na solidariedade e na interdependência dos indivíduos.

$\mathrm{Na}$ acepção de Bobbio, citado por Bonavides (2005), a comunidade é a emergência natural de um grupo com características que independem da vontade dos componentes do grupo, como é o caso da família. Para o autor, no processo evolutivo surgiu primeiro a comunidade, e posteriormente a sociedade. "A comunidade é matéria e substância, a sociedade é forma e ordem". Concluindo, afirma que na sociedade a solidariedade é mecânica, enquanto na comunidade ela é orgânica; no primeiro caso trata-se de uma organização, enquanto no segundo, de um organismo.

Pode-se exemplificar esse processo observando-se os grupos sociais amazônicos que emigraram de outros Estados brasileiros (em sua maioria, nordestinos assolados pela seca e atraídos pela promessa de sucesso com a atividade de resinagem da seringueira). Posteriormente abandonados pelos patrões e pelo Estado, com a crise econômica dessa atividade, passaram a viver em comunidades (RIBEIRO, 2006).

O conceito contemporâneo de Estado, segundo Bonavides (2005), emana de três troncos do conhecimento: filosófico, jurídico e sociológico. A acepção filosófica assenta seus princípios nas ideias do pensador Hegel, que definiu Estado como "a realidade da ideia moral; a substância ética consciente de si mesma; a manifestação visível da divindade". A jurídica foi trazida por Kant (1974), para quem o Estado é "a reunião de uma multidão de homens vivendo sob as leis do Direito". Bonavides (2005) menciona que Georgio Del Vecchio reputa a definição de Kant como inexata. Apesar de suas raízes kantistas, afirma que ele não foi além das limitações jurídicas formalistas do kantismo, ao definir o Estado como "o sujeito da ordem jurídica na qual se realiza a comunidade de vida de um povo", ou "a expressão potestativa da sociedade", desprezando os elementos constitutivos do Estado, muito embora, no que tange à ótica essencialmente jurídica, ele tenha colocado com lucidez que "o Estado é o laço jurídico ou político, ao passo que a sociedade é uma pluralidade de laços". Assinala ainda, o mesmo autor, que o pensador Georgio Burdeau conceituava Estado no mesmo teor jurídico, reforçando o aspecto institucional do poder, enunciando que "o Estado se forma quando o poder assenta numa instituição e não num homem". Essa concepção é complementada por Jean-Yves Calvez: "O Estado é generalização da sujeição do poder ao direito, por uma certa despersonalização". Das ideias de Georgio Burdeau sob a análise de Jean-Yves Calvez, o autor conclui que o Estado só é factível (ou existirá) quando concebido o poder independentemente da pessoa do governante.

Quanto à acepção sociológica, Bonavides (2005) faz alusão a pensadores como Oswaldo Spengler, Freuz Oppenheimer e Duguit, entre outros, para elucidá-la. Sob a égide do pensamento sociológico de Oppenheimer, "o Estado, pela origem e pela essência, não passa daquela instituição social, que um grupo vitorioso impôs a um grupo vencido, com o único fim de organizar o domínio do primeiro sobre o segundo e resguardar-se contra rebeliões intestinas e agressões estrangeiras". Para o autor, o Estado constitucional contemporâneo guarda fortes vínculos com a teoria de Oppenheimer, no que concerne a sua "índole organizacional da violência e do jogo econômico a que uma classe submete a outra", sustentada pela passagem pronunciada por Oppenheimer: "Pela forma esse Estado é coação, e 
pelo conteúdo exploração econômica". Bonavides considera a posição sociológica de Duguit na definição de Estado na mesma linha de pensamento de Oppenheimer, por definir Estado como "grupo humano fixado em determinado território, onde os mais fortes impõem aos fracos sua vontade". No tronco sociológico de Marx e Engels, estes explicam, segundo o autor, o estado como fenômeno histórico passageiro. A alegação é que as instituições nem sempre existiram, e que nem sempre existirão. Marx define Estado como "o poder organizado de uma classe social para opressão de outra", e Engels como "uma organização da respectiva classe exploradora para manutenção de suas condições externas de produção, a saber, para a opressão das classes exploradas".

Todavia, Bonavides (2005), em sua análise, descreve que o conceito de Estado "repousa na organização ou institucionalização da violência, segundo a análise mais profunda da sociologia política", reaparecendo com Max Weber, que o reconhece como a derradeira fonte de legitimidade, concernente à utilização da força física ou material. O autor recorre aos elementos constitutivos do Estado reconhecidos pela teoria política para elucidar o conceito de Estado. Elenca então, como elemento de ordem formal, o poder político na sociedade; de ordem material, o elemento humano, que constitui a população, povo e nação, em termos demográficos, jurídicos e culturais; e conclui com o elemento espacial, o território, o qual corresponde com o pensamento de Duguit, que define Estado como um "grupo humano fixado num determinado território". Apesar de Duguit incorporar os elementos constitutivos do Estado em sua descrição, Bonavides rejeita a proposição do autor, que considera que o Estado exprime a dominação dos mais fortes sobre os mais fracos. E adota, finalmente, o conceito apresentado por Jellinek, para quem o Estado é "a corporação de um povo, assentada num determinado território e dotada de um poder de mando".

Na perspectiva de Bobbio et al. (2004), jaz no mundo contemporâneo uma relevante complexidade na definição de Estado, face à dificuldade de se analisar o emaranhado das inter-relações entre este e a teia social, e de apreender, posteriormente, as suas implicações inerentes à racionalidade interna do sistema político. Sob essa complexidade apontada pelos autores, o entendimento do Estado contemporâneo passa por uma investigação do estado de direito com o conteúdo do social. No princípio do Estado, os direitos fundamentais constituíam a caução de uma sociedade burguesa à parte do Estado, contudo, os direitos sociais denotam a via pela qual a sociedade penetra no Estado, modificando-lhe a estrutura formal. Resulta, todavia, na derrocada do Estado burguês e na gradual interrogação do Estado político pela sociedade civil, resultando, por conseguinte, numa alteração da forma jurídica do Estado, e nos processos de legitimação e de estrutura administrativa.

Para os autores, as mudanças ocorridas nas estruturas material e social do sistema jurídico derivam das transformações em nível formal e político. Essas mudanças exprimem algumas tendências do século XIX e início do século XX, que levaram à expansão dos mercados das grandes potências com a introdução tecnológica e a formação das grandes empresas e formações planificadas do 'capital humano', bem como a afirmação do nacionalismo econômico, posto a serviço da ideologia de desenvolvimento, dando forma ao capitalismo organizado. Nesse contexto, mudou também a função de Estado na política econômica, que no século XVIII contribuiu para a criação de uma forma de mercado baseada não só em mercadorias como também no trabalho, no dinheiro e na terra, limitando-se posteriormente à garantia formal da estrutura da livre troca, sucedendo um Estado intervencionista no processo de valorização capitalista ou no processo de formação de valor do capital.

Emerge no início deste século o questionamento no que diz respeito ao Estado fiscal, como reflexo das transformações ocorridas na estrutura material e social do Estado de direito. O debate foca a necessidade da recapitalização do Estado e assume tal necessidade de satisfazer as exigências sociais (minadas na revolução industrial que perdura e se agrava contemporaneamente), discutindo o âmago da dinâmica econômica quanto à possibilidade da transformação do livre jogo concorrencial das forças de mercado, já evidenciado por Schumpeter em 1918, citado por Bobbio et al. (2004).

Sob a égide da teoria do Estado contemporâneo emanada do tronco marxista, ostentado na lógica da valorização do capital fundada no conflito de classes sociais e na contradição dos diversos setores do capital, distinguem-se funções essenciais desempenhadas pelo Estado contemporâneo, segundo Altvater na interpretação de Bobbio et al. (2004): i) criação das condições materiais genéricas de produção (infraestrutura); ii) determinação e salvaguarda do sistema geral das leis que compreendem as relações dos sujeitos jurídicos e na sociedade capitalista; iii) regulamentação dos conflitos entre trabalho assalariado e capital; iv) segurança e expansão do capital nacional total no mercado capitalista mundial. 
Esse postulado nega, por sua vez, a tênue função de Estado atribuída por Adam Smith e David Ricardo, que excluem o Estado do processo de acumulação, devendo este atuar apenas nas funções de manutenção das instituições militares, policiais, educativas e jurídicas, o resto ficando a cargo da lógica de mercado. Logo há a necessidade de o Estado socializar os benefícios da economia, ou seja, disciplinar o conjunto da sociedade civil e o peso da valorização exclusiva do setor econômico mais desenvolvido, criando assim mecanismos para frear a queda da taxa média de lucro por meio de uma cota de capital constante. Isso é a origem do documento da despesa pública, justificando assim o intervencionismo do Estado (BOBBIO et al., 2004).

Ainda do ponto de vista dos autores, a crescente integração de Estado e sociedade civil, ou seja, a "tendência das políticas públicas assegurarem o equilíbrio dos interesses emergentes", pode ser analisada nas despesas públicas, como instrumento de investigação da conexão sociedade-Estado. Todavia, a análise política se atém às estruturas institucionais, e não ao político em si. A indagação reclama o fundamento da política, podendo-se, a partir daí, inferir-se sobre a transformação do político e a sua adequação à nova complexidade da sociedade civil.

Segundo Weber (1999), as raízes do Estado contemporâneo emanam do direito romano e do direito canônico, aliança esta na qual o capitalismo encontrou sustentação e teve ascensão como Estado nacional. Na concepção sociológica weberiana, o Estado é "aquela comunidade humana que, dentro de determinado território, reclama para si o monopólio da coação física legítima". O autor alega que se existisse apenas um complexo social que desconhecesse o meio da coação, não haveria necessidade do conceito de "Estado", dar-se-ia lugar à "anarquia" no sentido específico do termo.

O Estado weberiano "é uma associação de dominação institucional que dentro de determinado território pretendeu com êxito monopolizar a coação física legítima como meio da dominação e, para esses fins, reuniu nas mãos de seus dirigentes os meios materiais de organização, depois de desapropriar todos os funcionários estamentais autônomos que antes dispunham, por direito próprio, em seu lugar, representado por seus dirigentes supremos".

Esse é o Estado moderno, que se apossou das ideias administrativas weberianas e que, em associação com as ideias econômicas keynesianas, deu sustento à expansão do capitalismo pelo Ocidente até o Oriente, estendido ao mundo moderno, à vida cotidiana.

\section{Funções de Estado e crescimento do Estado}

A teoria sistêmica do Estado contemporâneo procede de um sistema político constituído dos três poderes - legislativo, executivo e judiciário - instituídos por uma sociedade política (BOBBIO, 2007).

O princípio do crescimento do Estado deu-se na primeira guerra mundial, precipuamente com a demanda de estrutura e custos dos Estados durante a segunda guerra mundial. Os poderes constitucionais dos Estados cresceram de forma vertiginosa, através dos instrumentos do poder público: no controle das atividades econômicas - tributação, regulamentação e incentivos -; como árbitro do social - pobreza, desigualdade e distribuição da renda -; e na garantia dos direitos e deveres do cidadão - direito do privado e da coletividade, segurança etc. Na interpretação de Przeworsky (1995), esse é o momento da história econômica em que o Estado alcança a habilidade de dirigir a economia, motivando os atores econômicos a buscar o controle do Estado.

O keynesianismo revelou-se como um dos sustentáculos dos litígios constitutivos da democracia capitalista, em que cabia ao Estado conciliar propriedade privada e gestão democrática da economia (MALUF, 1997).

Kalecki (1977) assinala que a estrutura produtiva é parte da mesma moeda da estrutura distributiva da renda. Portanto, a estrutura distributiva é a principal responsável pela má ou boa distribuição da renda, que no caso do Brasil tem sido responsável pela má distribuição.

O Estado, no seu processo evolutivo histórico, foi acumulando ineficiências à medida que respondia a pressões conflitantes, como a acumulação e a legitimação da propriedade privada (PRZEWORSKY, 1995).

O papel do Estado concerne à coordenação da alocação de recursos, das qualidades distributivas do bem-estar, das estruturas alternativas de propriedade e das estratégias de desenvolvimento, asseguradas pelas constituições das nações sob regime democrático.

No mundo contemporâneo, a economia dirige o jogo do mercado, e o Estado a condiciona e ao mesmo tempo tenta corrigir as falhas do mercado através das decisões tomadas pelo poder público. Essas 
falhas são intrínsecas à história biológica e social, que faz emanar as disparidades da propriedade, da capacidade e das oportunidades. Na amálgama dos programas públicos, Samuelson (1988) afirma que o Estado desempenha funções econômicas, a saber: i) estabelecer o enquadramento legal; ii) determinar a política de estabilização macroeconômica; iii) influir na alocação de recursos para aumentar a eficiência econômica; iv) estabelecer programas que influenciem a distribuição do rendimento. $\mathrm{O}$ autor diz ainda que o Estado dita as regras do jogo de mercado com a promulgação de leis como resposta a valores e ideias de justiça amplamente compartilhadas, como resultado de uma análise detalhada de custobenefício.

Ainda na perspectiva de Samuelson, a macroeconomia nas administrações públicas modernas busca amenizar os ciclos da atividade econômica, evitando o desemprego crônico e o crescimento débil, além de conter a inflação. $\mathrm{O}$ autor assinala que, para contornar os desequilíbrios na área econômica, sentidos em todo o mundo, uma nova área vem sendo explorada, denominada escolha pública. Significa a tomada de decisão pelo poder público, procurando identificar quais os bens adquiridos, para quem são destinados os custos e benefícios dos seus programas e como são produzidos esses bens.

Os Estados constituem organizações complexas, sobretudo nos países latinos-americanos após a crise econômica dos anos 80, apresentando contemporaneamente um alto grau de complexidade para atender suas funções. Dentre as dificuldades enfrentadas pelo Estado, Przeworsky (1992) aponta a estrutura econômica como limitação de ação dos governos, vez que os agentes econômicos privados, dotados de liberdade de ação no capitalismo, podem tornar algumas formas de intervenção estatal estruturalmente impossível. Por exemplo, a capacidade de trabalho e o capital privado conferem barreiras às funções de Estado, pelo fato de que este não pode comandar nem a capacidade de trabalho nem o capital privado para desempenhar determinada atividade ou investimento.

Se o Estado tomou sua verdadeira forma com o desenvolvimento do capitalismo, ou seja, para administrar o regime de propriedade, consequentemente as funções de Estado no mundo contemporâneo derivam em grande parte da necessidade de disciplinar o sistema de propriedade privada.

Referindo-se às falhas de mercado, Zylbersztajn (1995) caracteriza duas evidências como pressupostos dessas falhas, com base nas teorias trabalhadas por Williamson, a da racionalidade limitada e a do oportunismo. A racionalidade limitada decorre do esforço racional, mas consegue êxito apenas de forma limitada. Logo, a competência limitada de receber, estocar, recuperar e processar informação - as inventividades incompletas - deriva da racionalidade limitada. Para o autor, o oportunismo é uma ação dos indivíduos de forma ávida, arraigada no conservadorismo do ser, na tentativa do máximo acúmulo de bens de capital, relegando os princípios éticos impostos pela sociedade como condutas a serem respeitadas pelas coletividades nas transações comerciais e financeiras.

Stiglitz (1998) questiona o argumento de que os mercados são alocadores eficientes de recursos. O autor nega a argumentação de que o livre mercado atinge a eficiência pelo processo da "mão invisível, que, por ser invisível, logo não existe". Para Furtado (2000), os mercados só geram decisões coerentes em países com avançado grau de homogeneidade social. Przeworsky (1992) faz remissão a Kenneth Arrow, um dos formuladores do argumento sobre mercados eficientes, para desmistificar essa premissa. Segundo o autor, Arrow demonstrou em 1964 que a premissa dos mercados completos - que existe um mercado para cada estado contingente da natureza -, não se sustenta, tendo em vista que alguns mercados futuros, principalmente o mercado de risco, são inevitavelmente insuficientes. O problema diz respeito, portanto, a desvendar mecanismos institucionais específicos, dotados de poder e legitimidade capazes de oferecer aos agentes econômicos incentivos e informações que lhes permitam agir de forma racional. De um outro ponto de vista, Maluf (2000) apresenta uma proposta de abandonar a "enganosa" dicotomia Estado versus mercado em benefício de uma "compreensão distinta da própria natureza dos mercados e dos mecanismos regulatórios, que lhe são inerentes, aos quais compete atribuir um sentido público".

Maluf (1997) chama a atenção para um aspecto interessante no processo histórico dos comportamentos teóricos no tempo. Nas décadas de 1940/50, as teorias atribuíam a necessária intervenção governamental na economia devido às falhas do mercado e ao não-funcionamento adequado do sistema de preços. No início dos anos 60 e até a década de 80 , emerge a ideia de que as falhas do mercado são pormenores frente às falhas do governo, reforçada pelo ressurgimento da economia neoclássica em decorrência das dificuldades enfrentadas pelo keynesianismo, por suas limitações teóricas e como fonte dos referidos alicerces. 
Samuelson (1988) assinala que as disparidades econômicas entre indivíduos e grupos sociais são em parte advindas da riqueza ou inteligência herdadas dos pais, dos preços dos mercados, dos serviços que podem oferecer e das sortes, quer dizer, de eventos casuais fortuitos. Para Furtado (1992), as desigualdades socioeconômicas existentes em determinadas economias refletem a distribuição de ativos, no momento em que tem início o processo de crescimento da produtividade, e também a natureza das instituições que regulam a acumulação de ativos. Pelo menos do ponto de vista teórico, os Estados, sobretudo os de economias avançadas, executam, através das instituições, a transferência de ativos via programas sociais, seguridade social (condições mínimas de alimentação, saúde e educação) e encargos tributários diferenciados para os extratos sociais.

A teoria da escolha pública apresentada por Samuelson (1988), inerente à tomada de decisão pelo Estado, trata do cumprimento das funções de Estado como rezam os princípios éticos e os ditames legais das doutrinas no combate às falhas do mercado e do próprio Estado diante do jogo político e do nível de utilidade. O prelúdio da escolha pública pelo Estado é a análise do que, como e para quem das decisões exteriores ao mercado na alocação de recursos. A escolha pública implica a convergência das preferências coletivas, no nível de utilidade ou rendimento líquido almejado pelos diferentes grupos sociais através dos conselhos e parlamentos democráticos.

Não obstante, as falhas do mercado e de intervenção do governo evidenciam pontos, como custos e benefícios de determinadas atividades, que se estendem a outras pessoas (ou grupos de indivíduos) sem que estas sejam compensadas ou tenham responsáveis que arquem com os custos pelos danos ou benefícios - poluição, bens e serviços públicos, como segurança, saúde pública, conservação dos recursos naturais, infra-estrutura etc. (SAMUELSON, 1988).

Por se tratar de funções de Estado, um questionamento se torna evidente: de onde o Estado extrai seu poder concernente à área florestal? Do ponto de vista de Przeworsky (1995), concernente à vida econômica, a resposta centrada pura e simplesmente no monopólio da coação física é fraca, porque essa não é a única fonte concebível de poder do Estado, assim como a premissa de que esse poder provém em qualquer lugar da força física perde credibilidade do ponto de vista democrático das civilizações contemporâneas. Além do mais, no mundo capitalista as decisões de alocação de recursos são descentralizadas, e numa economia descentralizada a força não é suficiente para governar efetivamente. Sob a perspectiva de Przeworsky (1995), o poder dos Estados pode derivar do fato de que certas tarefas, sejam elas quais forem, podem ser exercidas em base universalista, com custos providos pelos membros da sociedade, bem como serviços estatais definidos pelo conjunto da sociedade, como infraestrutura, proteção e meio ambiente. Os Estados podem extrair poderes dos valores que condicionam os indivíduos a reconhecerem sua autoridade, legitimidade etc., como valores que fazem com que as pessoas desempenhem ações com base nas decisões estatais na ausência da coação física. Como expressa o autor, chega até a ser paradoxal, mas o Estado pode derivar seu poder do fato de se constituir numa arena de conflito entre outras organizações, que se sustenta na prerrogativa de invocar um interesse superior, que transcende as demais partes envolvidas. Em síntese o Estado deve perseguir o bem comum, porém somente a força física é capaz de assegurar que ele seja endogenamente coeso e exogenamente eficaz em face de interesses conflitantes.

Explicitado sucintamente, os princípios dos quais o Estado extrai seu poder são traduzidos e ratificados pela sociedade na sua Carta Política e demais ditames legais, regras e costumes socialmente aceitos. Logo, o Estado brasileiro incorpora suas funções na área florestal a partir do arcabouço legal estatuído e dos valores socioculturais de seu povo em face das florestas como elementos da natureza, sentimentos estes teoricamente expressos nos processos sociais. Contudo, o arcabouço legal e os valores socioculturais são dinâmicos e se alteram no tempo.

\section{As inter-relações das funções de Estado na área florestal com a Constituição Federal}

Possivelmente, os primeiros escritos sobre funções de Estado foram apresentados por Aristóteles no seu livro VI, capítulo VIII, da Política. Discorrendo sobre as funções de governo na cidade, o filósofo afirma que todas as cidades têm funções a serem cumpridas, assim como uma cidade só pode ser bem administrada se o bom exercício das funções que resguardam a ordem e a harmonia for cumprido. Ao magistrado eram atribuídas as funções para fazer cumprir a ordem do comércio e dos contratos; as funções da administração da cidade e sua jurisdição eram denominadas "inspetoria da cidade"; os magistrados atribuídos da função territorial eram chamados de "administradores da terra e/ou inspetores 
das florestas". O surgimento das funções de Estado nas cidades era também, automaticamente, estendido às florestas, ao se atribuir o ordenamento territorial, bem como a administração das florestas, ao magistrado (ARISTÓTELES, 2006).

Aristóteles descreveu os eventos das relações dos indivíduos e grupos familiares e suas organizações em sociedade e Estado, usando como elemento central a natureza. Ao considerar o todo a unidade central, e não as partes - sendo que o todo deve, imprescindivelmente, ser posto antes da parte, ou seja, a sociedade é a unidade, e não o indivíduo -, sustenta a necessidade da instituição da organização social. A esse respeito, assim se expressou: "Levantai o todo: dele não restará nem pé nem mão senão no nome, como se poderá afirmar, por exemplo, que a mão separada do corpo não será mão senão pelo nome. Todas as coisas são definidas pelas suas funções: e desde o instante em que elas venham a perder os seus característicos, não mais se poderá afirmar que são as mesmas; somente ficam entendidas sob a mesma denominação". Daí se extrai a justificativa de que o Estado, na ordem da natureza, antepõe o indivíduo. Pois se cada indivíduo se encerra em si mesmo, não é o suficiente; do mesmo modo acontecerá com as partes em relação ao todo. Logo, se o indivíduo de nada necessita porque em si se encerra, não é um ser sociável e, por conseguinte, não participa do Estado: "é um bruto ou uma divindade" (ARISTÓTELES, 2006).

Esses princípios da função da cidade e da relação Estado-indivíduo, trazidos à luz por Aristóteles, demonstram que tanto a essência da Carta Política de 1988 como o Código Florestal de 1965 apresentam fundamentos consistentes ao considerar respectivamente o meio ambiente ecologicamente equilibrado como bem comum do povo, e as florestas e demais formas de vegetação como bens de interesse comum a todos os habitantes do país. Assim, é função do Estado coordenar em conjunto com a sociedade a questão florestal, pelo caráter indissociável da relação Estado-indivíduo. Isso torna, por sua vez, as terras florestais privadas passíveis de desapropriação, quando entendido pelo poder público a necessidade de declará-las como bem de interesse social, para fins de conservação e proteção. É função do Estado construir em conjunto com a sociedade os princípios e normas legais de uso e conservação das terras florestais públicas e privadas. As ações em terras florestais privadas estão submetidas às normas legais de uso e conservação. Logo, o livre arbítrio do indivíduo no uso de suas terras florestais está submetido aos ditames legais erigidos pela sociedade e para a sociedade, representada na máquina administrativa do Estado, que se antepõe ao indivíduo, através de suas estruturas institucionais de incentivo e coação.

Na concepção de Achaval (2007), o conceito de função de Estado diz respeito essencialmente às relações do Estado com a comunidade política. Para o autor, as funções de Estado visam o bem comum e assegurar a liberdade dos indivíduos, funções estas corporificadas na Constituição do país e assentadas nos três poderes do Estado - o legislativo, o executivo e o judiciário. A natureza de cada função está relacionada com a tripartição dos poderes do Estado, com cada órgão estatal que a cumpre e com os entes que os constituem.

Andrade (1993) aponta que o Estado moderno tem uma tríade de funções básicas a ser desempenhada: i) funções de Estado stricto sensu: manutenção da ordem interna, defesa do território, representação externa, provimento da justiça, tributação e administração dos serviços que presta; ii) funções de Estado na economia: criação e administração da moeda nacional, regulamentação dos mercados e promoção de desenvolvimento (planejamento, criação de incentivos, produção de bens, de infraestrutura e de insumos estratégicos etc.); iii) funções de Estado na área social: provimento universal dos bens sociais fundamentais (saúde, educação, habitação), cobertura dos riscos sociais, proteção dos setores mais necessitados etc.

Sob a perspectiva desse autor, as funções stricto sensu de Estado são intangíveis, exclusivas e intransferíveis, sendo o Estado, e somente ele, com seus meios próprios, apto a exercê-la. No campo econômico, são exclusivas somente as atividades regulatórias, e as funções no campo social são, em última instância, do Estado, podendo, porém, ser exercidas tanto pelo Estado quanto pelo setor privado.

$\mathrm{Na}$ leitura de Bobbio (2007), sob uma visão sistêmica do Estado, fica estabelecida uma ampla interpretação das funções do Estado na sociedade, desde a proposição conceitual para análise do funcionamento das instituições políticas até a própria função que lhe é inerente. Essa gama de funções perpassa o princípio da relação demanda-resposta, isto é, a relação do conjunto das instituições políticas com o sistema social, em que aquelas têm como função prover as respostas e este sintetiza as demandas do ambiente social. 
Com base nos poderes constitucionais do Estado, estatuídos na Carta Magna de 1988, no Código Florestal e nas demais leis endereçadas ao uso, conservação e proteção dos recursos florestais, o Estado tem seis funções típicas que lhe são inerentes na área florestal. Elas estão inter-relacionadas às funções de Estado no controle das atividades econômicas (tributação, regulamentação e incentivos), no controle social (pobreza, desigualdade e distribuição da renda) e no estabelecimento de direitos e deveres do cidadão (direito do privado e da coletividade, segurança etc.).

Tabela 1. Funções de estado na área florestal e suas inter-relações com a Constituição Federal de 1988. Table 1. Functions of state in the forest area and its inter-relations with the Federal Constitution of 1988.

\begin{tabular}{|c|c|}
\hline Função de Estado & Constituição Federal de 1988 \\
\hline $\begin{array}{l}\text { Realizar o macroplanejamento } \\
\text { da proteção e utilização dos } \\
\text { recursos florestais. }\end{array}$ & $\begin{array}{l}\text { Art. } 21 \text { (inciso XVIII) - Planejar e promover a defesa permanente contra as } \\
\text { calamidades públicas, especialmente as secas e as inundações; } \\
\text { Art. } 174 \text { - O Estado é agente normativo e regulador da atividade econômica, } \\
\text { exercendo, na forma da lei, a fiscalização, incentivo e planejamento, sendo } \\
\text { determinante para o setor público e indicativo para o setor privado. }\end{array}$ \\
\hline $\begin{array}{l}\text { Administrar as áreas florestais } \\
\text { públicas. }\end{array}$ & $\begin{array}{l}\text { Art. } 23 \text { (inciso VII) - É competência comum da União, dos Estados, do } \\
\text { Distrito Federal e dos Municípios: preservar as florestas, a fauna e a flora; } \\
\text { Art. } 24 \text { (inciso VI) - Compete à União, aos Estados e ao Distrito Federal } \\
\text { legislar concorrentemente sobre florestas [...] e proteção da natureza; } \\
\text { Art. } 225 \text { (inciso III) - Definir, em todas as unidades da federação, espaços } \\
\text { territoriais e seus componentes a serem legalmente protegidos. }\end{array}$ \\
\hline $\begin{array}{l}\text { Prover extensão e assistência } \\
\text { técnica florestal. }\end{array}$ & $\begin{array}{l}\text { Art. } 187 \text { (inciso IV) - A política agrícola será planejada e executada, na forma } \\
\text { da lei [...], levando em conta, especialmente: assistência técnica e extensão } \\
\text { rural. }\end{array}$ \\
\hline Promover o fomento florestal. & $\begin{array}{l}\text { Art. } 22 \text { (inciso VII) - Compete privativamente à União legislar sobre política } \\
\text { de crédito; } \\
\text { Art. } 174 \text { - o Estado é agente normativo e regulador da atividade econômica; } \\
\text { Art. } 187 \text { (inciso I) - a política agrícola será planejada e executada [...], levando } \\
\text { em conta, especialmente: - os instrumentos creditícios e fiscais. }\end{array}$ \\
\hline Realizar a pesquisa florestal... & $\begin{array}{l}\text { Art. } 218 \text { - O Estado promoverá e incentivará o desenvolvimento científico, a } \\
\text { pesquisa e a capacitação tecnológicas. }\end{array}$ \\
\hline $\begin{array}{l}\text { Monitorar e fiscalizar a } \\
\text { cobertura florestal dos } \\
\text { proprietários privados }\end{array}$ & $\begin{array}{l}\text { Art. } 21 \text { (inciso XVIII) - Compete à União planejar e promover a defesa } \\
\text { permanente contra as calamidades públicas, especialmente as secas e as } \\
\text { inundações; } \\
\text { Art. } 23 \text { (inciso VII) - É competência comum da União, dos Estados, do } \\
\text { Distrito Federal e dos Municípios: - preservar as florestas, a fauna e a flora; } \\
\text { Art. } 225 \text { - É dever do poder público e da coletividade defender e preservar o } \\
\text { meio ambiente ecologicamente equilibrado. }\end{array}$ \\
\hline
\end{tabular}

\section{Funções de Estado e conteúdo de política florestal}

A primeira função típica de Estado na área florestal é realizar o macroplanejamento da proteção e utilização dos recursos florestais, o qual deve servir como instrumento indicativo para planos, projetos e ações de governo. As ações de governo, mesmo claramente definidas, perderão em eficiência e eficácia diante da indisponibilidade de informações e ferramentas para planejamento que permitam mensurar o status e a dinâmica da proteção, conservação e uso dos recursos florestais (SILVA, 2001 e 2003).

Essa função encontra respaldo no art. 21, inciso XVIII da Constituição Federal de 1988 (Tabela 1), o qual atribui à União o planejamento e a promoção da defesa permanente contra as calamidades públicas, especialmente as secas e as inundações, e no art. 174, que coloca o Estado como agente normativo e regulador da atividade econômica, atribuindo-lhe as funções de incentivo e planejamento e estabelecendo bases e diretrizes para o desenvolvimento do país de forma equilibrada. Assim, o Estado é responsável pelo planejamento do uso adequado dos recursos naturais disponíveis e pela preservação do meio ambiente. $\mathrm{O}$ art. 187, que trata da política agrícola, legitima a participação dos atores envolvidos na cadeia produtiva do setor agrícola no planejamento e execução, e inclui no bojo do planejamento agrícola, ainda que de forma equivocada, a atividade florestal.

Essa função de Estado não aparece claramente como conteúdo de política na primeira gestão do Programa Nacional de Florestas (PNF-2000). No documento oficial do programa constam dez linhas 
temáticas que, no conjunto, não permitem estabelecer uma associação direta com macroplanejamento, conforme aqui colocado. Já a segunda gestão do programa (PNF-2004) avançou nesse tema, embora ele não estivesse explicitado claramente para a sociedade em suas linhas de ação, quando da reafirmação do programa durante a posse da Comissão Coordenadora do Programa Nacional de Florestas (CONAFLOR), em evento realizado em Brasília em fevereiro de 2004. No decorrer da gestão do programa, foram incorporadas em suas linhas de ação a elaboração de um projeto de Inventário Florestal Nacional (IFN) e a estruturação de um Sistema de Informações Florestais. Esse projeto foi construído pela coordenação do programa em conjunto com instituições de pesquisa e universidades, ouvida a sociedade em dois seminários. Tanto o IFN quanto o sistema de informações são instrumentos fundamentais para o macroplanejamento setorial e de outros setores produtivos e para acompanhamento pela sociedade.

A segunda função de Estado é administrar as áreas florestais públicas. O primeiro Plano Anual de Outorga Florestal, concluído em julho de 2007, cadastrou 193,8 milhões de hectares de florestas públicas federais (22\% da superfície territorial brasileira), dos quais $92 \%$ localizam-se na Amazônia (PAOF, 2007). A adição das áreas dos estados, das quais ainda não se dispõe de uma estimativa consolidada, certamente elevará para $1 / 3$ ou mais do território nacional a administração estatal direta de florestas públicas. A relevância dessa função estatal induziu à aprovação de uma lei específica de gestão dessas florestas e à criação de um órgão federal para geri-las, o Serviço Florestal Brasileiro.

Além do art. 225 - dedicado ao meio ambiente -, que determina reservar espaços territoriais protegidos em todas as unidades da federação, essa função se funda também no art. 23, inciso VII da Constituição Federal, que atribui ao poder público, nas três instâncias de governo (Federal, Estadual e Municipal) preservar as florestas, a fauna e a flora, assim como no art. 24, que atribui às instâncias federal e estadual legislar concorrentemente sobre florestas e proteção da natureza (Tabela 1).

As duas gestões do PNF trataram dessa função, ao menos como conteúdo de política. O PNF2000 tratou-a na linha temática "Expansão e consolidação do manejo de florestas em áreas públicas e fortalecimento institucional". Porém não foram encontrados indicadores consistentes que permitissem mensurar as ações atinentes às metas estabelecidas. No PNF-2004, essa função de Estado foi apresentada como "Expansão da área manejada associada à proteção de áreas com alto valor ecológico" e "Regularização fundiária", posteriormente incluída na linha de ação "Regulamentação". A consecução legal deu-se com a lei de Gestão de Florestas Públicas, que estabeleceu três modalidades de gestão, e com criação do Serviço Florestal Brasileiro, instituição surgida com a finalidade de gerir as áreas de florestas públicas.

Além das terras públicas caracterizadas como unidades de conservação de acordo com o SNUC, existem ainda as terras de dominialidade pública ou devolutas, que devem ser administradas pelo Estado. $\mathrm{Na}$ exposição de motivos que embasou a lei de gestão de florestas públicas, consta que $42 \%$ das terras florestais da região amazônica são devolutas, $29 \%$ são terras legalmente protegidas (unidades de conservação e terras indígenas) e os $24 \%$ restantes estão sob regime de propriedade privada.

A terceira função de Estado na área florestal é assistência técnica e extensão florestal à clientela florestal (ATEF). Aqui, faz-se remissão ao art. 187 da Carta Política, que aborda o planejamento da política agrícola, que deverá levar em conta, dentre outras atribuições, a assistência técnica e a extensão rural (inciso IV). Todavia, a extensão florestal e a prestação de assistência técnica correspondem à transferência ao produtor rural de conhecimentos e técnicas provindos da ciência, e o uso dessas técnicas é o progresso técnico, desenvolvido na academia e demais unidades de pesquisa. A extensão florestal vai além da assistência técnica propriamente dita, abarcando o conjunto de demandas das distintas políticas públicas referentes às populações das florestas. A ATEF, por sua vez, segue um modelo de desenvolvimento adotado pelas agências de governo, derivado do macroplanejamento do país.

Historicamente, o cumprimento dessa função se constituiu num dos gargalos do desenvolvimento florestal, pois o Estado brasileiro nunca a incorporou como uma atividade permanente. O PNF-2000 explicitou em seu documento oficial uma linha temática: "Fortalecimento Institucional e Extensão Florestal", que propôs criar e promover a figura do "fazendeiro florestal". Para a conjuntura da geração da sociedade do conhecimento, do Brasil que busca uma reestruturação da sua teia social, essa denominação soa arcaica, tendo em vista que a figura do "fazendeiro" é associada à imagem de uma estrutura social rural conservadora. Ações nessa temática foram empreendidas pelo PNF com o lançamento de edital, pelo Pro-Manejo (Projeto de Apoio ao Manejo Florestal Sustentável), para a contratação e capacitação de técnicos destinados a atuar na área de manejo sustentável na Amazônia. No 
PNF-2004 foi criada uma linha de ação que trata de "Capacitação e Assistência Técnica", cuja ratificação resultou na criação do Centro Nacional de Apoio ao Manejo Florestal (CENAFLOR). Esse centro destinase à capacitação de recursos humanos e "formação de agentes multiplicadores", tarefa esta que poderá vir a ser fortalecida pelo Serviço Florestal Brasileiro (SFB), criado em março de 2006. Mas, talvez num ato falho, o documento do programa, quando se refere a extensão, menciona extensão rural, quando deveria enfatizar florestal. A sociedade em geral associa atividade rural com agricultura e pecuária, desconsiderando quase sempre a floresta e as possibilidades do manejo sustentável dos recursos florestais.

A quarta função de Estado na área florestal é promover o fomento florestal, para a consecução da atividade florestal. O crédito é essencial para o desenvolvimento do setor florestal, requerendo atenção especial do governo na negociação de taxas de juros e tempo de carência com as instituições financeiras, para que de fato os pequenos e médios produtores florestais possam acessá-lo, tendo em vista que a atividade florestal é de longo prazo.

Essa é uma função de Estado por excelência, por competir privativamente à União a política de crédito (CF, art. 22, inciso VII). Está expressamente contemplada nos artigos 174 e 187, que concernem, respectivamente, aos incentivos concedidos ao setor produtivo e à criação e viabilização de instrumentos creditícios e fiscais para a política agrícola. Há de se considerar que a geração de emprego depende de investimento tanto pelo setor público como pelo privado, e fomentar investimento mesmo do setor privado é responsabilidade do Estado - pelo menos é por ele disciplinado e acompanhado. Nesse sentido, o artigo 170, que aborda a ordem econômica, prega a busca do pleno emprego, e este só é gerado através dos investimentos, principalmente no setor privado. Indubitavelmente, essa função de Estado é essencial para o crescimento econômico e para a geração de emprego. Nesse particular, a atividade florestal, sobretudo a primária, é grande geradora de empregos e fixadora de mão-de-obra. Essa função foi contemplada nas duas versões do PNF. Na de 2000, em três de suas linhas temáticas: expansão da base florestal plantada, expansão e consolidação do manejo de florestas nativas em áreas públicas e manejo de florestas nativas em áreas privadas; a de 2004 tratou essa função de forma mais veemente, lançando como um dos focos o programa "Crédito para o setor florestal".

A quinta função de Estado, realizar a pesquisa florestal, é fundamental, pois alicerça o desenvolvimento do setor florestal, proporcionando a geração de novas tecnologias, métodos de manejo, geração de estatísticas e indicadores, aproveitamento e agregação de valor aos produtos florestais e aumento de produtividade. A Constituição Federal, no capítulo IV - Da ciência e tecnologia -, trata, no artigo 218, da promoção, incentivo e desenvolvimento da ciência e tecnologia, pesquisa e capacitação tecnológica do país, tendo a pesquisa científica e tecnológica como prioridade do Estado, visando o bem público e a solução de problemas regionais e nacionais, bem como o desenvolvimento dos sistemas produtivos.

As duas versões do PNF atenderam essa função como conteúdo de política florestal, embora o país ainda não disponha de uma política explícita de pesquisa e desenvolvimento florestal (P\&D). Na segunda gestão do Programa, foram traçadas a linhas gerais de um "Plano Nacional de Pesquisa em Silvicultura com Espécies Nativas (PENSAF)", que, sem prejuízo de seus possíveis benefícios, aborda apenas questões pontuais e não abarca a temática florestal no conjunto, requerendo do poder estatal uma política de P\&D florestal.

A sexta função típica de Estado é monitorar e fiscalizar a cobertura florestal dos proprietários privados. Essa função foi uma das primeiras a serem ensaiadas pelo poder público na história florestal brasileira e incorporada ao primeiro Código Florestal do país, editado em 1934. Fazendo-se remissão à Carta Política de 1988, o artigo 21 trata do planejamento e defesa contra calamidades públicas, como secas e enchentes, e como as áreas de reserva legal e de preservação permanente têm função de evitá-las ou atenuá-las, esse artigo contempla, em parte, essa função de Estado, complementado pelo disposto no art. 23, que dispõe sobre a proteção do meio ambiente (inciso VI) e a preservação das florestas, da fauna e da flora (inciso VII). Além da Constituição, leis específicas, como o Código Florestal de 1965, que cria as áreas de reserva legal e de preservação permanente, como a lei da Política Nacional do Meio Ambiente (6.938/81) e como a lei de Crimes Ambientais (9.605/98), leis estas voltadas, no conjunto, ao uso e conservação e proteção dos recursos florestais, reclamam o cumprimento dessa função de Estado, também referendada no artigo 225 da Constituição de 1988, que assinala que é de responsabilidade do poder público e da coletividade defender e preservar o meio ambiente. Para o cumprimento dessa função, as duas gestões do PNF coerentemente adotaram como conteúdo de política uma linha de ação específica 
denominada "Monitoramento e Controle". Embora o presente estudo não abarque a mensuração de sua eficácia, o cumprimento dessa função envolve grande complexidade. Trata-se de uma função que o Estado brasileiro encontra dificuldade em cumprir e fazer cumprir. Uma nova perspectiva emergiu com a descentralização da gestão florestal, que visa compartilhar essa função com os Estados da federação, a partir da alteração promovida no art. 19 do Código Florestal pela lei 11.284/06. Estudo recente, realizado na Bolívia, mostrou que no princípio a descentralização da gestão florestal apresenta baixa eficácia, pela deficiência institucional e de recursos humanos, como mostra um estudo de caso na Bolívia (ANDERSSON, 2005).

Essa função de monitoramento e controle é conteúdo de política explícito no PNF. Deve-se observar, no entanto, que ações extras ao programa foram desenvolvidas com vistas a mitigar efeitos do desmatamento na Amazônia. Essas ações foram iniciadas com a instituição do Grupo Permanente de Trabalho Interministerial, pelo Decreto s/n de 3 de julho de 2003, posteriormente revisto através do Decreto s/n de 15 de março de 2004. Como conteúdo de política de ações emergenciais, o governo federal empreendeu esforços com o lançamento, em março de 2004, do plano de combate ao desmatamento naquela região, cuja análise foge ao objetivo deste trabalho. Contudo, o conteúdo do plano desdobrou-se em várias ações, dentre as quais mencionam-se a lei de gestão de florestas públicas, a criação do distrito florestal sustentável da BR-163, a integração da geração e acompanhamento de dados relativos ao desmatamento, o reforço na fiscalização e o recadastramento das propriedades rurais situadas na área de influência do avanço do desmatamento na região Amazônica (Portaria 010 do Ministério do Desenvolvimento Agrário/Instituto Nacional de Colonização e Reforma Agrária - MDA/INCRA).

As funções típicas de Estado na área florestal, apontadas por Silva (2001 e 2003), foram aqui consubstanciadas com a leitura da Constituição brasileira. Porém, fazer cumprir essas funções pelo poder público depende do processo político, do sinergismo entre Estado, sociedade e academia e dos imprescindíveis e adequados arranjos institucionais. A capacidade de desenvolvimento de mecanismos e instrumentos para a consecução das funções de Estado na área florestal permeia desde o desenho institucional até o sinergismo e o contínuo processo da dinâmica política. Isso implica um profundo estudo do estado da arte da questão florestal, em todos os seus aspectos - político, científico, tecnológico, de inovação, de mercado, de administração, de desenho institucional, de demandas internas e externas, de tendências de mercado etc.

A inserção da questão florestal no eixo do desenvolvimento do país, bem como na dinâmica econômica das nações, é fundamental para se atingir o tão perseguido desenvolvimento sustentável. Todavia, para que essa inserção se dê no eixo da dinâmica econômica no médio prazo, esforços devem ser canalizados, como jamais o foram, para essa questão. A opção pelo modelo de desenvolvimento próprio pode tornar o setor florestal um setor da economia tão dinâmico quanto qualquer outro, desde que colocado como prioridade pelo Estado e ser devidamente incentivado por ele.

\section{Avaliação das funções de Estado na área florestal}

$\mathrm{O}$ resultado da pesquisa realizada junto a membros da Conaflor sobre as funções de Estado, propostas no arcabouço teórico para análise da política pública florestal, estão sumarizados na Tabela 2. O resultado revelou uma aceitação das funções de Estado elencadas (73\% a 91\% de sim aos itens apresentados). A pesquisa realizada corrobora a metodologia proposta para o estudo, como um lineamento teórico de formulação e análise parcial do processo político florestal, tanto pela academia quanto pela sociedade.

Tabela 2. Resultados relativos às respostas dos membros da Conaflor à pergunta: "Você considera como função típica de Estado na área florestal".

Table 2. Relative results to the answers of the members of Conaflor to the question: "You consider as typical function of State in the forest area".

\begin{tabular}{llcc}
\hline \multirow{2}{*}{ Funções típicas de Estado } & \multicolumn{1}{c}{$(\boldsymbol{\%})$} \\
\cline { 2 - 4 } & Sim & Em parte & Não \\
\hline 1. & Realizar o macroplanejamento da proteção e utilização dos recursos & 91 & 9 \\
$\quad$ florestais. & 82 & 18 \\
2. Administrar as áreas florestais públicas. & 73 & 18 & 9 \\
3. Prestar assistência técnica e extensão florestal. &
\end{tabular}


4. Promover o fomento da atividade florestal.

$91 \quad 9$

5. Realizar a pesquisa florestal. $\quad 73 \quad 27$

6. Monitorar, controlar e fiscalizar a cobertura florestal dos proprietários $\quad 73 \quad 27$ privados.

O resultado da avaliação do cumprimento das funções peculiares do Estado brasileiro foi qualificado como precário (55\% a $82 \%$ ), apresentando uma nota $\leq 5,0$ para uma pontuação de 0 a 10 (Tabela 3).

Tabela 3. Resultado relativo às respostas dos membros da Conaflor à pergunta: "O Estado vem desenvolvendo essa função" (\%).

Table 3. Relative result to the answers of the members of Conaflor to the question: "The State is developing this function" (\%).

\begin{tabular}{|c|c|c|c|c|c|}
\hline & Plenamente & Razoavelmente & Precariamente & $\begin{array}{c}\text { Não } \\
\text { desenvolve }\end{array}$ & $\begin{array}{c}\text { Nota } \\
\text { (média) }\end{array}$ \\
\hline $\begin{array}{l}\text { 1. Realizar o macro planejamento da } \\
\text { proteção e utilização dos recursos } \\
\text { florestais. }\end{array}$ & & 27 & 73 & & 4 \\
\hline $\begin{array}{l}\text { 2. Administrar as áreas florestais } \\
\text { públicas. }\end{array}$ & & 10 & 80 & 10 & 4 \\
\hline $\begin{array}{l}\text { 3. Prestar assistência técnica à } \\
\text { clientela florestal. }\end{array}$ & & 9 & 82 & 9 & 3 \\
\hline $\begin{array}{l}\text { 4. Promover o fomento da atividade } \\
\text { florestal. }\end{array}$ & & 18 & 73 & 9 & 4 \\
\hline 5. Realizar a pesquisa florestal. & & 36 & 55 & 9 & 5 \\
\hline $\begin{array}{l}\text { 6. Monitorar, controlar e fiscalizar a } \\
\text { cobertura florestal dos } \\
\text { proprietários privados. }\end{array}$ & & 18 & 64 & 18 & 3 \\
\hline
\end{tabular}

Embora essas funções tenham sido reconhecidas como válidas pelos entrevistados na pesquisa realizada, assim como sua sustentação teórica - abordada no presente estudo -, na visão dos entrevistados o Estado brasileiro não está desenvolvendo seu papel na sua plenitude. Isso indica deficiência advinda do processo político, sugerindo que o cerne da questão pode ser subjacente aos princípios desse processo. O resultado pode estar refletindo o entendimento dos princípios de política pública e da capacidade do governo, no contexto de um país em busca dos caminhos para o crescimento econômico e desenvolvimento de seu povo.

As respostas da pesquisa sobre o esforço do PNF para o cumprimento das funções de Estado atribuíram uma qualificação de precário (30\% a 80\%) a razoável (10\% a 60\%), e uma nota de desempenho $\leq 5.0$ (Tabela 4).

Tabela 4. Resultado relativo às respostas dos membros da Conaflor à pergunta: "O PNF tem contribuído para que essa função seja desenvolvida" $(\%)$.

Table 4. Relative result to the answers of the members of Conaflor to the question: "PNF has been contributing so that this function is developed" (\%).

\begin{tabular}{|c|c|c|c|c|c|c|}
\hline & & Plenamente & Razoavelmente & Precariamente & $\begin{array}{c}\text { Não } \\
\text { contribui }\end{array}$ & $\begin{array}{c}\text { Nota } \\
\text { (média) }\end{array}$ \\
\hline 1. & $\begin{array}{l}\text { Realizar o macroplanejamento da } \\
\text { proteção e utilização dos recursos } \\
\text { florestais. }\end{array}$ & & 60 & 30 & 10 & 5 \\
\hline 2. & Administrar as áreas florestais públicas. & & 40 & 60 & & 5 \\
\hline 3. & $\begin{array}{l}\text { Prestar assistência técnica à clientela } \\
\text { florestal. }\end{array}$ & & 44 & 56 & & 5 \\
\hline 4. & $\begin{array}{l}\text { Promover o fomento da atividade } \\
\text { florestal. }\end{array}$ & & 30 & 70 & & 5 \\
\hline 5. & Realizar a pesquisa florestal. & & 20 & 70 & 10 & 4 \\
\hline 6. & Monitorar, controlar e fiscalizar a & & 10 & 80 & 10 & 3,6 \\
\hline
\end{tabular}


$\mathrm{O}$ resultado da pesquisa permite um entendimento do processo que envolve o Estado, o setor florestal e o conteúdo da política pública. Esse entendimento evidencia que o Estado, a despeito do esforço para atender as demandas a ele atribuídas, com a criação da Conaflor, deixa transparecer certa fragilidade na concepção e instrumentalização da política.

Os resultados da pesquisa ratificam as funções de Estado como válidas, ao passo que atribuem uma qualificação ao desempenho do Estado e do próprio PNF como precário a razoável no cumprimento dessas funções.

Os termos usados, Estado e PNF, no trato com a temática florestal, podem parecer ambíguos, pelo fato do PNF ser o responsável pela questão no âmbito do poder público federal. Enquanto o primeiro trata da atenção dada pela gestão de governo ao tema, dentro do macroplanejamento e das ações do governo federal (refletido no repasse de recursos e no fortalecimento institucional), o segundo diz respeito ao esforço da gestão do Programa, ou seja, abarcar as funções de Estado no processo político e perseguir o cumprimento dessas funções. Os resultados instigam e sugerem ao poder público o uso de lineamento teórico de princípios orientadores no processo de formulação da política florestal, assim como no seu curso de ação, devidamente acordados com a sociedade.

Há uma outra perspectiva na interpretação da pesquisa, em relação ao desempenho do Estado e da gestão do programa. Pode ter havido uma branda compreensão dos entrevistados acerca da distinção entre o cumprimento das funções pelo Estado e o esforço da gestão do PNF. A gestão do programa pode estar se empenhando para desenvolver o melhor possível o seu papel, ao passo que as instâncias superiores de governo podem simplesmente não ter colocado a política florestal como prioridade na agenda administrativa.

Cumpre aqui salientar as limitações da pesquisa, pois não foi possível realizar uma análise estatística mais detalhada dos dados, devido ao número reduzido de questionários respondidos. A Conaflor é constituída por 36 membros, número que permitiria obter significância estatística nos resultados, caso todos tivessem respondido. No entanto, apenas doze questionários foram respondidos. A pesquisa limitou-se aos participantes da reunião de Imersão do PNF, e, dentre estes, aos que responderam o questionário. A despeito disto, deve-se olhar para a metodologia como mais um instrumental teórico de análise da política pública florestal a ser explorado futuramente, além dos mecanismos do poder público federal, como o Plano Plurianual (PPA) e os demais resultados apresentados pelos relatórios do órgão gestor.

A impossibilidade da utilização de um método único em estudos sobre o Estado revela que os resultados devem ser integrados numa síntese, e, de acordo com o ângulo que esteja sendo focado, poderá haver um método mais adequado "podendo perfeitamente ocorrer de uma lei geral, obtida por indução, tirando-se deduções que irão explicar os fenômenos, havendo, portanto, uma associação permanente de métodos, assim como os próprios fenômenos estão sujeitos a uma interação causal, uma vez que a vida social está sempre submetida a um processo dialético", o que faz da realidade social uma permanente criação (DALLARI, 2005).

\section{CONCLUSÕES}

O processo histórico Estado-sociedade permite elucidar o crescimento das funções do Estado e a relevância delas no seio da sociedade, assim como a relação recíproca sociedade-Estado, a qual, com o decorrer dos tempos, permeia também os recursos florestais. As funções do Estado tipificam-se então na área florestal, por via compulsória, em face da importância que aqueles recursos assumem para o conjunto da sociedade nos tempos atuais. Esse processo evolutivo atribui robustez teórica ao liame Estadosociedade-recursos florestais, fundamentando assim o desenvolvimento de políticas públicas atinentes aos recursos florestais.

A revisão das funções de Estado em geral, e daquelas na área florestal em particular, instiga novas formas de pensar sobre o do papel do Estado na sociedade, hoje, e sobre a postura desta, e de ambos (Estado e sociedade) relativamente às florestas, na busca do equilíbrio das funções de produção, ambiental e sociocultural das florestas e dos recursos florestais no seu conjunto. 
As funções de Estado se justificam em face do seu papel de exercer o bem comum, pautado nas necessidades de orientação das suas ações, na busca da eficiência e da eficácia, no atendimento das demandas sociais e no combate à iniquidade.

Para todas as funções típicas de Estado levantadas e analisadas no presente estudo, encontraramse inter-relações com dispositivos da Constituição Federal do Brasil de 1988, a saber: macroplanejamento (arts. 21 e 174), administração de florestas públicas (arts. 23, 24 e 225), extensão e assistência técnica florestal (art. 187), fomento florestal (arts. 22, 174 e 187), pesquisa florestal (art. 218) e monitoramento e fiscalização das florestas (arts. 21, 23 e 225).

A política pública florestal brasileira explicitada no Programa Nacional de Florestas permeia o conjunto das funções típicas de Estado na área florestal, tomadas como referencial teórico de análise neste estudo, mas ainda depende de ser consolidada para cumprir integralmente esse conjunto de funções.

Embora essas funções tenham sido reconhecidas como válidas pelos entrevistados na pesquisa realizada, na visão deles o Estado brasileiro não vem desenvolvendo ainda, na plenitude, as seis funções estatais típicas na área florestal.

As funções de Estado na temática florestal permitem o estudo/análise do processo político florestal desde a constituição da política até a sua revisão. O conjunto dessas funções pode servir como mais um alicerce teórico no processo de formação de política pública florestal, tomadas para o entendimento do liame político-institucional a ser desempenhado pelo Estado em consonância com a sociedade.

A consubstanciação das funções de Estado na área florestal pela Constituição Federal permite minimizar as falhas de políticas e os concomitantes arranjos institucionais, na medida em que tipifica as responsabilidades do Estado assim como a postura e os compromissos da sociedade em face dos recursos florestais, não só diante das gerações presentes como também das gerações futuras.

\section{AGRADECIMENTOS}

Os autores agradecem ao Programa Nacional de Florestas, em especial ao seu então Diretor Tasso Rezende de Azevedo, a Ednardo de Freitas Machado, pelo apoio no fornecimento de informações e para a realização da pesquisa com os membros da Conaflor, bem como aos participantes dessa Comissão que contribuíram com o trabalho respondendo aos questionários.

\section{REFERÊNCIAS}

ANDRADE, R. C.; JACCOUD, L. de B. Estrutura e Organização do Poder Executivo. Administração Pública Brasileira, Brasília, DF, v. 2, p. 28, 1993.

ARISTÓTELES. Política. Tradução de Pedro Constantin Tolens. São Paulo: Martin Claret, 2006.

AICHER, C. A política florestal européia: um sonho ou uma realidade? Ciência Florestal, Santa Maria, v. 14 , n. 2 , p. $177-188$, set. de 2004.

ACHAVAL, M. D. Funciones del Estado. Disponível em: <http://www.todoelderecho.com/marco_maestro.htm?http://www.todoelderecho.com/Destacados/bol1.ht m>. Acesso: 22/05/2007.

BRASIL. Programa Nacional de Florestas - PNF. 2 ed.. Brasília, DF, MMA/SBF/DIFLOR, 2001.

BOBBIO, N.; MATTEUCCI, N.; PASQUINO, G. Dicionário de política. Tradução de Carmen C. Varriale et. al. Brasília, DF,: Universidade de Brasília, 12 ed., 2004.

BOBBIO, N. Estado, governo, sociedade: para uma teoria geral da política. 13 ed.; tradução de Marco Aurélio Nogueira. Rio de Janeiro: Paz e Terra, 2007.

BONAVIDES, P. Ciência Política. 11 ed.. São Paulo: Malheiros, 2005. 
BRASIL. Ministério do Meio Ambiente. Áreas protegidas do Brasil. Disponível em: $<$ http://www.mma.gov.br/tomenota.cfm?tomenota=/port/sbf/dap/capa/index.html\&titulo $=\ddot{i} i{ }^{1 / 2}$ ? reas $\% 20 \mathrm{Pr}$ otegidas>. Acesso em: 19/06/2007.

CARNEIRO, N. I. Cadeira de política florestal. Curitiba, Escola de Florestas - PR, 1969. Departamento de publicações, Diretório Acadêmico Bernardo Saião, Gestão 1968/69.

DALLARI, D. A. Elementos de teoria geral do Estado. 25 ed.. São Paulo: Saraiva, 2005.

FURTADO, C. A nova dependência: divida externa e modernismo. São Paulo: Paz e Terra, 1982.

. Brasil: opções futuras. Revista da CEPAL, Chile, n. 70, abril, 2000.

HOBBES DE MALMESBURY, T. Leviatã. Tradução de João Paulo Monteiro e Maria Beatriz Nizza da Silva. São Paulo: Abril S. A. Cultural e Industrial, 1974.

KALECCKI, M. Crescimento e ciclos das economias capitalistas. Tradução de Jorge Miglioli. São Paulo: Hucitec, 1977. Capítulo 12.

KANT, I. Crítica da razão pura e outros textos filosóficos. Tradução de Valério Rohden. São Paulo: Abril S. A. Cultural e Industrial, 1974.

MALUF, R. S. Atribuindo sentido(s) à noção de desenvolvimento econômico. Revista Estudos, Sociedade e Agricultura, Rio de Janeiro, v. 1, n. 15, p. 51-85, 2000.

MATURANA, H. R. Emoções e linguagem na educação e na política. Tradução de José Fernando Campos Fortes. Belo Horizonte: Ed. UFMG, 1998.

MONTESQUIEU. Do espírito das leis. Tradução publicada sob licença de Difusão Européia do Livro. São Paulo: Abril S. A. Cultural e Industrial, 1973.

PRZEWORSKY, A. A Falácia Neoliberal, Lua Nova, S. Paulo, v. 28/29, 1993.

PRZEWORSKY, A. Estado e Economia no capitalismo. Tradução de Argelina Cheibug Figueiredo e Pedro Paulo Zahluth Bastos. Rio de Janeiro: Ed. Dumará, 1995.

RIBEIRO, D. O povo brasileiro: a formação e o sentido do Brasil. São Paulo: Companhia das Letras, 2006.

ROUSSEAU, J. J. Discurso sobre a origem e os fundamentos da desigualdade entre os homens. Tradução de Lourdes Santos Machado. São Paulo: Abril S. A. Cultural e Industrial, 1973.

SAMUELSON, P. A.; NORDHAUS, W. D. Economia. 12 ed. São Paulo: McGraw-Hill, 1988. Caps. 13, 16 e 32 .

SANTOS, A. J. Contribuição para a formulação da política florestal brasileira. Floresta, Curitiba, v. 23, n. 1/2, p. 63-73, jul./dez.1993.

SILVA. J. de A. 2001. As funções de Estado na área florestal. Revista Floresta e Ambiente, Rio de Janeiro, v. 8, p. 223-226, 2001.

Quebrando castanha e cortando seringa. Seropédica: EDUR, 2003. 137 p.

STIGLITZ, J. Em busca de um novo paradigma para o desenvolvimento: estratégias, políticas e processos. Genebra: Instituto Mundial para a Pesquisa em Desenvolvimento Econômico - UNCTDA, 1998.

WEBER, M. Economia e sociedade: fundamentos da sociologia compreensiva. Tradução de Regis Barbosa e Karen Elsabe Barbosa. 3 ed. Brasília, DF: Editora Universidade de Brasília, 1999. v. 2.

ZYLBERSZTANJ, D. Estrutura de governança e coordenação do agribusines: uma aplicação da nova economia das instituições. São Paulo: Universidade de São Paulo, 1995. 